\title{
Bioactive Compounds of Flaxseed as Natural Antioxidants and Anticancer
}

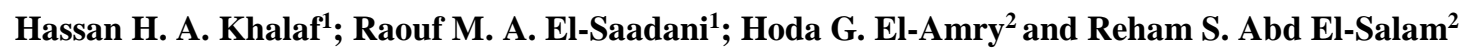 \\ ${ }^{1}$ Food Technology Department, Faculty of Agriculture, Benha University, Egypt. \\ ${ }^{2}$ Food Technology Research Institute, Agricultural Research Center, Giza, Egypt.
}

\begin{abstract}
The objective of this study was to investigate the content of biologically active compounds and antioxidant activity (AOA) of full fat flaxseed flour (FFF), roasted full fat flaxseed flour (RFFF), defatted flaxseed flour (DFF) and roasted defatted flaxseed flour (RDFF) flour as well as to evaluate anticancer effect of lignans ethanolic extracts from defatted and roasted defatted flaxseed for in vitro cytotoxicity against breast and colon carcinoma cell lines. The results revealed that roasted defatted flaxseed flour samples (RDFF) contained higher values of crude protein $(32.86 \%)$, ash $(6.60 \%)$, crude fiber $(14.03 \%)$ and total carbohydrate $(42.16 \%)$ than other flaxseed flour samples. Results showed that RDFF had significantly $(\mathrm{P}<0.05)$ the highest amounts of total phenolic contents, total flavonoid contents, tannins content and antioxidant activity $(871.15 \mathrm{mg}$ GAE/100g, $199.12 \mathrm{mg}$ $\mathrm{CE} / 100 \mathrm{~g}, 83.51 \mathrm{mg} \mathrm{CE} / 100 \mathrm{~g}$ and $78.99 \%$, respectively). Meanwhile, FFF contained the lowest values $(643.04 \mathrm{mg}$ GAE/100g, $112.46 \mathrm{mg} \mathrm{CE} / 100 \mathrm{~g}, 60.33 \mathrm{mg} \mathrm{CE} / 100 \mathrm{~g}$ and $75.80 \%$, respectively). It was observed that, ferulic acid was the predominant phenolic acid in defatted flaxseed samples. Also, Secoisolariciresinol diglucoside (SDG) is the predominant lignans precursor present in flaxseed. Furthermore, DFF and RDFF were higher in lignans values compared to that of full fat and roasted full fat flaxseed flours. Cytotoxicity effect of lignans ethanolic extracts from defatted and roasted defatted flaxseed on colon carcinoma cell line (HCT) and breast carcinoma cell line (MCF-7) increased as the extract concentration increased. RDFF had strong anticancer activity toward two tested cell lines (MCF-7 and HCT) with the half maximal inhibitory concentration ( $\left.\mathrm{IC}_{50}\right)$ values $(29.0$ and $31.4 \mu \mathrm{g} / \mathrm{ml}$, respectively). While, defatted flaxseed revealed anticancer activity against (HCT) cell line (with value $48.2 \mu \mathrm{g} / \mathrm{ml}$ of $\left.\mathrm{IC}_{50}\right)$ compared to $(\mathrm{MCF}-7)$ cell line at concentration under investigation $(12.5,25,50$ and $100 \mu \mathrm{g} / \mathrm{ml}$ of lignans extract).
\end{abstract}

Keywords: Flaxseed, defatted flaxseed flour, roasted flaxseed flour, bioactive compounds, antioxidant activity, anticancer activity.

\section{Introduction}

Flaxseed or linseed (Linum usitatissimum L.), a member of the family Linaceae, is an economically important oilseed crop containing approximately about $40 \%$ of oil in the seeds. The generally recognized as safe (GRAS) status of flaxseed has been confirmed (Jheimbach and Port Royal, 2009). Flaxseed is important source of oil and protein for industrial, pharmaceutical, and nutritional applications (Han et al., 2018).

Flaxseed is emerging as one of the key source of phytochemicals and an important functional food ingredient in the recent years because of its high content of $\alpha$-linolenic acid (ALA, omega-3 fatty acid) and phytoestrogenic lignans especially (secoisolariciresinol diglycoside, SDG). Moreover, it is a good source of high quality and digestible protein, dietary fiber (soluble fiber and insoluble fiber), vitamins, minerals and phenolic compounds (Oomah, 2001 and Rubilar et al., 2010). Scientific evidences support consumption of flaxseed provides potential health benefits in the prevention of some chronic diseases such as decreasing the risk of cardiovascular disease (CVD), lowering cholesterol, atherosclerosis, reducing blood pressure, diabetes and protect against cancer (Jhala, 2010 and Bernacchia et al., 2014).
Flaxseed cake (the defatted meal), a by-product that results from flaxseed cold pressing process after extraction of flaxseed oil, has been used as livestock feed, and little attention has been given to its chemical properties and nutritional value (Simbalista et $\boldsymbol{a l}$., 2012). It is represents a cheap raw material for antioxidant (phenolic compounds especially lignans). So, flaxseed cake provides the flaxseed industry with value-added co-products. Considering its high protein content, dietary fiber and lignans content, defatted flaxseed meal is a remarkable source for food ingredient used in human food and food additive production (Mueller et al., 2010).

Roasting of flaxseed enhanced the desired nutty flavor, color and overall acceptability. This heat treatment modifies the cellular structure facilitating the extraction of antioxidants. Furthermore, it helps to improve the availability of nutrients, inactive enzymes which accelerate nutrient damage, destroy undesirable microorganisms and food contaminants. Also, roast processing effectively reduced the antinutritional factors like cyanogenic glycosides (Pittia et al., 2001 and Khan and Saini, 2016).

Considering the nutritional value and associated health benefits of consuming flaxseed. The purpose of the present work was planned to study the phytochemical profiles of flaxseed and defatted flaxseed flour as well as evaluate their antioxidant 
activity. Anticancer effect of lignans extract from defatted flaxseed was examined for in vitro cytotoxicity against colon and breast carcinoma cell lines.

\section{Materials And Methods}

\section{Materials}

Brown flaxseed variety (Linum usitatissimum L.), named "Sakha 2" was grown during season (2016) and obtained from the Fiber Crops Research Department, Field Crops Research Institute (FCRI), Agricultural Research Center (ARC), Giza, Egypt.

Colon carcinoma cell line (HCT), breast carcinoma cell line (MCF-7) and test kits were obtained from Pharmacology Unit, Cancer Biology Department, National Cancer Institute, Egypt.

\section{Methods}

\subsection{Preparation of flaxseed samples}

The cleaned whole flaxseed was mixed homogenously and divided into two parts: the first part was milled raw flaxseed using a coffee grinder (Braun Model KMM30, Germany) to obtain full-fat flaxseed flour (FFF), the second part was roasted in air oven at 80$90^{\circ} \mathrm{C}$ for $10 \pm 15$ min until a nutty flavor was developed. After cooling at room temperature for 30 min, the roasted samples were immediately milled as roasted full-fat flaxseed flour (RFFF) according to method described by Chetana et al. (2010) and Marpalle et al. (2014). Half of the both FFF and RFFF were partially defatted by extracting the flaxseed oil through cold solvent extraction. Samples were shaked for $30 \mathrm{~min}$ by horizontal shaker using $n$ hexane $(1: 6 \mathrm{w} / \mathrm{v})$ and left in dark for $24 \mathrm{~h}$ at room temperature. The mixture was filtered and the residue was re-extracted for another two days to remove lipids from sample with renewal of hexane every $6 \mathrm{~h}$. The defatted flaxseed flour (DFF) and roasted defatted flaxseed flour (RDFF) were air dried at room temperature for $24 \mathrm{~h}$ in order to remove the remaining $n$-hexane. All types of flour samples were kept in polyethylene bags and stored at -18 to $-20^{\circ} \mathrm{C}$ until used for analysis (Gaafar et al., 2013 and Omran et al., 2016).

\subsection{Chemical analysis}

The proximate chemical composition (moisture, crude protein, fat, crude fiber and ash contents) of flaxseed flour samples (FFF, RFFF, DFF and RDFF) were determined according to the methods of AOAC (2012). Total carbohydrate was calculated by difference.

\subsection{Determination of phytochemical profiles of} flaxseed flours

2.3.1. Determination of total phenolic compounds

Total phenolic content (TPC) was determined calorimetrically by using Folin-Ciocalteau reagent according to the method of Manukumar and Thribhuvan (2014).

\subsubsection{Fractionation of phenolic compounds using} HPLC

The phenolic compounds of flaxseed flour samples (DFF and RDFF) were extracted according to the method described by Hakkinen et al. (1998) using HPLC instrument (Hewlett Packard, series 1050, USA) equipped with column $\mathrm{C}_{18}$ hypersil BDS with particle size $5 \mu \mathrm{m}$. Quantification was carried out for a calibration based on the standard phenolic acids.

\subsubsection{Determination of total flavonoid content}

Total flavonoid content (TFC) was determined using aluminum chloride colorimetric method as described by Zhishen et al. (1999).

\subsubsection{Determination of tannins content}

Quantitative determination of tannins was carried out as described by Price $\boldsymbol{e t}$ al. (1978) followed with minor modification by Osman (2004).

\subsubsection{Determination of antioxidant activity by} using DPPH radical scavenging method

The antioxidant activity was determined based on the radical scavenging ability in reacting with a stable DPPH free radical according to the method of BrandWilliams et al. (1995). Antioxidant activity was calculated as $\%$ of radical scavenging percentage using the following equation:

$\%$ radical scavenging percentage $=\left[\left(\mathrm{A}_{0}-\mathrm{A}_{1}\right) / \mathrm{A}_{0}\right] \times 100$

Where: $A_{0}=$ the absorbance of the control reaction (containing all reagents except the test compounds).

$\mathrm{A}_{1}=$ the absorbance in the presence of the tested extracts after $30 \mathrm{~min}$.

2.3.6. Identification of flaxseed lignans by HPLC

The lignans compounds in flaxseed flour samples were extracted according to the method outlined by Ezzat et al. (2018). HPLC analysis was carried out using an Agilent 1100 series HPLC system.

\subsection{Anticancer activity of flaxseed}

\subsubsection{Preparation of flaxseed lignans extracts}

The lignans compounds (SDG) from defatted flaxseed and roasted defatted flaxseed samples were separately extracted according to the method described by Zhang et al. (2007).

\subsubsection{In vitro cytotoxicity (SRB assay)}

Flaxseed lignans extracts were tested against colon carcinoma cell line (HCT) and breast carcinoma cell line (MCF-7). The percentage of cell death was estimated by SRB (Sulfo-Rhodamine-B) assay. Potential cytotoxicity of ethanolic extracts of lignans from flaxseed was tested using the method of Skehan et al. (1990) as follow:

Cells were plated in 96-multiwell plate $\left(10^{4}\right.$ cells/well $)$ for $24 \mathrm{~h}$ before treatment with the lignans compound to allow attachment of cell to the wall of the plate. Different concentrations of the flaxseed lignans extracts under investigate $(12.5,25,50$ and $100 \mu \mathrm{g} / \mathrm{ml})$ were added to the cell monolayer triplicate wells which were prepared for each individual dose. Monolayer cells were incubated with the lignans 
compound for $48 \mathrm{~h}$ at $37^{\circ} \mathrm{C}$ and in atmosphere of $5 \%$ $\mathrm{CO}_{2}$. After $48 \mathrm{~h}$, cells were fixed, washed and stained with Sulfo-Rhodamine-B stain. Excess stain was washed with acetic acid and attached stain was recovered with Tris EDTA buffer. Color intensity was measured by ELISA reader (TCAL). The relation between surviving fraction and drug concentrations was plotted to get the survival curve of each tumor cell line after treatment of flaxseed lignans.

\subsection{Statistical analysis}

The obtained data were exposed to analysis of variance ANOVA (one-way analysis of variance). Duncan's multiple test at 5\% level was used to compare the significant differences between means (Steel and Torrie, 1997).

\section{Results and Discussion}

1. Proximate chemical composition of flaxseed flours

Table (1) shows the proximate chemical constituents of different flaxseed flour samples. The results revealed that roasted flaxseed samples (RFFF and RDFF) contained higher values of crude protein (20.49 and $32.86 \%$ ), ash (4.16 and 6.60\%), crude fiber $(8.74$ and $14.03 \%)$ and total carbohydrate (27.27 and $42.16 \%$ ) than those of unroasted flaxseed samples (FFF and DFF). Also, defatted flaxseed samples (DFF and RDFF) had the same trend in which those samples had significantly higher protein, ash, crude fiber and total carbohydrate values compared to FFF and RFFF.

Table 1. Chemical composition of flaxseed flours (\% on dwt $)^{*}$

\begin{tabular}{ccccc}
\hline Constituents & FFF & RFFF & DFF & RDFF \\
\hline Moisture & $5.0 \pm 0.16^{\mathrm{c}}$ & $2.82 \pm 0.03^{\mathrm{d}}$ & $9.51 \pm 0.29^{\mathrm{a}}$ & $7.70 \pm 0.14^{\mathrm{b}}$ \\
Crude protein & $20.20 \pm 0.14^{\mathrm{b}}$ & $20.49 \pm 0.32^{\mathrm{b}}$ & $32.78 \pm 0.51^{\mathrm{a}}$ & $32.86 \pm 0.65^{\mathrm{a}}$ \\
Fat & $40.76 \pm 0.04^{\mathrm{a}}$ & $39.34 \pm 0.09^{\mathrm{b}}$ & $4.95 \pm 0.24^{\mathrm{c}}$ & $4.35 \pm 0.15^{\mathrm{d}}$ \\
Ash & $3.98 \pm 0.06^{\mathrm{c}}$ & $4.16 \pm 0.03^{\mathrm{b}}$ & $6.58 \pm 0.14^{\mathrm{a}}$ & $6.60 \pm 0.04^{\mathrm{a}}$ \\
Crude fiber & $8.61 \pm 0.06^{\mathrm{c}}$ & $8.74 \pm 0.06^{\mathrm{c}}$ & $13.74 \pm 0.13^{\mathrm{b}}$ & $14.03 \pm 0.04^{\mathrm{a}}$ \\
Total carbohydrate** & $26.45 \pm 0.22^{\mathrm{b}}$ & $27.27 \pm 0.32^{\mathrm{b}}$ & $41.95 \pm 0.56^{\mathrm{a}}$ & $42.16 \pm 0.71^{\mathrm{a}}$
\end{tabular}

${ }^{*} \mathrm{dwt}=$ dry weight basis, $* *$ calculated by difference. $\mathrm{FFF}=$ full fat flaxseed flour, RFFF=roasted full fat flaxseed flour, $\mathrm{DFF}=$ defatted flaxseed flour, $\mathrm{RDFF}=$ roasted defatted flaxseed flour. Values are mean of three replicates \pm SD. Means followed by different superscripts within rows are significantly different at 0.05 level.

It was found that protein content of the seed decreased as the oil content increased. Differences on flaxseed composition could be attributed to genetic, growing environment factors, seed processing and method of analysis (Rubilar et al., 2010). The proximate composition of flaxseed shows the promising potential for utilization in different food product development. Similar findings were obtained by Manukumar et al. (2014) who showed that the nutritional composition of full fat flour (FFF) and partially defatted flaxseed flour (PDF) contained 20.12 and $28.16 \%$ protein, 36.43 and $5.12 \%$ fat, 3.13 and $4.94 \%$ ash, 7.80 and $11.10 \%$ crude fiber and 36.10 and $57.93 \%$ carbohydrates, respectively. However, they observed significant increase in the nutritive contents in the PDF.

\section{Phytochemical profiles of flaxseed flours}

Table 2. Phytochemicals content and antioxidant activity (AOA) of flaxseed flours (on dwt).

\begin{tabular}{|c|c|c|c|c|}
\hline Constituent & FFF & RFFF & DFF & RDFF \\
\hline $\begin{array}{c}\text { Total phenolic (mg } \\
\text { GAE/100g) }\end{array}$ & $643.04 \pm 2.60^{\mathrm{d}}$ & $683.35 \pm 2.27^{\mathrm{c}}$ & $858.20 \pm 1.59^{b}$ & $871.15 \pm 2.06^{\mathrm{a}}$ \\
\hline $\begin{array}{c}\text { Total flavonoid (mg } \\
\text { CE/100g) }\end{array}$ & $112.46 \pm 2.38^{\mathrm{d}}$ & $130.23 \pm 1.83^{\mathrm{c}}$ & $154.81 \pm 3.07^{\mathrm{b}}$ & $199.12 \pm 2.43^{a}$ \\
\hline Tannins (mg CE/100g) & $60.33 \pm 1.08^{d}$ & $69.14 \pm 1.64^{\mathrm{c}}$ & $74.58 \pm 1.44^{\mathrm{b}}$ & $83.51 \pm 2.09^{\mathrm{a}}$ \\
\hline AOADPPH $(\%)$ & $75.80 \pm 0.46^{\mathrm{c}}$ & $77.46 \pm 0.39^{\mathrm{b}}$ & $77.82 \pm 0.38^{\mathrm{b}}$ & $78.99 \pm 0.28^{\mathrm{a}}$ \\
\hline
\end{tabular}

Values are mean of three replicates \pm SD. Means followed by different superscripts within rows are significantly different at 0.05 level. 
The variation of the tannins content in the different studied flaxseed flours was observed. It was varied between roasted and unroasted either defatted or nondefatted flaxseed flours. The higher tannin content was recorded in RDFF and DFF (83.51 and $74.58 \mathrm{mg}$ $\mathrm{CE} / 100 \mathrm{~g}$, respectively). Meanwhile, RFFF and FFF contained the lower amounts of tannins (69.14 and $60.33 \mathrm{mg} \mathrm{CE} / 100 \mathrm{~g}$, respectively).

From results in the same Table, it could be observed that AOA of flaxseed flours was in the range of 75.80 to $78.99 \%$. Significantly, difference among flaxseed flour was found, with the highest activity being $78.99 \%$ in roasted defatted flaxseed flour (RDFF). While the lowest activity being $75.80 \%$ in full fat flaxseed flour (FFF).

From above results, it could be concluded that flaxseed possesses a very powerful natural antioxidant system. There is a great interest in finding new and safe antioxidants from natural sources. Flaxseed contained many natural sources of major plant phytochemicals such as phenolic acids, flavonoids, tannins, lignans and tocopherols (Oomah and Sitter, 2009). These results suggest that flaxseeds would be valuable candidates as functional products and dietary supplements production owing to the higher bioactive values such as phytochemicals compounds (Wang et al., 2017).

\subsection{Identification of phenolic compounds}

Phenolic compounds of defatted and roasted defatted flaxseed flours were extracted and fractionated by HPLC as presented in Table (3) and Figures (1 and 2).

Concerning flaxseed samples, roasted defatted flaxseed contained the higher amounts of most fractionated phenolic compounds than that of defatted flaxseed. Ferulic acid was the predominant phenolic acid in both flaxseed samples. In addition, roasted defatted flaxseed flour contained the higher level of chlorogenic acid, cinnamic acid, vanillic acid and $P$ hydroxybenzoic acid than that of defatted flaxseed.

The results are in the same trend with Hao and Beta (2012) who found that flaxseed contained ferulic acid, p-hydroxybenzoic, vanillic, protocatechuic, syringic, caffeic, sinapic acids.

Table 3. Phenolic compounds of defatted and roasted defatted flaxseed flours as $\mathrm{mg} / \mathrm{g}$ (on dwt).

\begin{tabular}{ccc}
\hline Phenolic compounds & DFF & RDFF \\
\hline Gallic acid & 3.34 & 3.89 \\
Catechol & 1.02 & 1.78 \\
$\boldsymbol{P}$-hydroxybenzoic acid & 2.78 & 3.89 \\
Caffeine & 1.78 & 1.95 \\
Vanillic acid & 4.99 & 5.11 \\
Caffeic acid & 2.44 & 2.43 \\
Syringic acid & 3.11 & 3.23 \\
Vanillin & 4.78 & 4.89 \\
$\boldsymbol{p}$ - Coumaric acid & 10.90 & 10.54 \\
Ferulic acid & 13.23 & 13.43 \\
Chlorogenic acid & 9.67 & 9.89 \\
Ellagic acid & 1.56 & 1.50 \\
Benzoic acid & 2.89 & 3.02 \\
$\boldsymbol{o}$ - Coumaric acid & 6.89 & 6.88 \\
Salicylic acid & 3.43 & 3.56 \\
Cinnamic acid & 5.90 & 5.95 \\
\hline
\end{tabular}




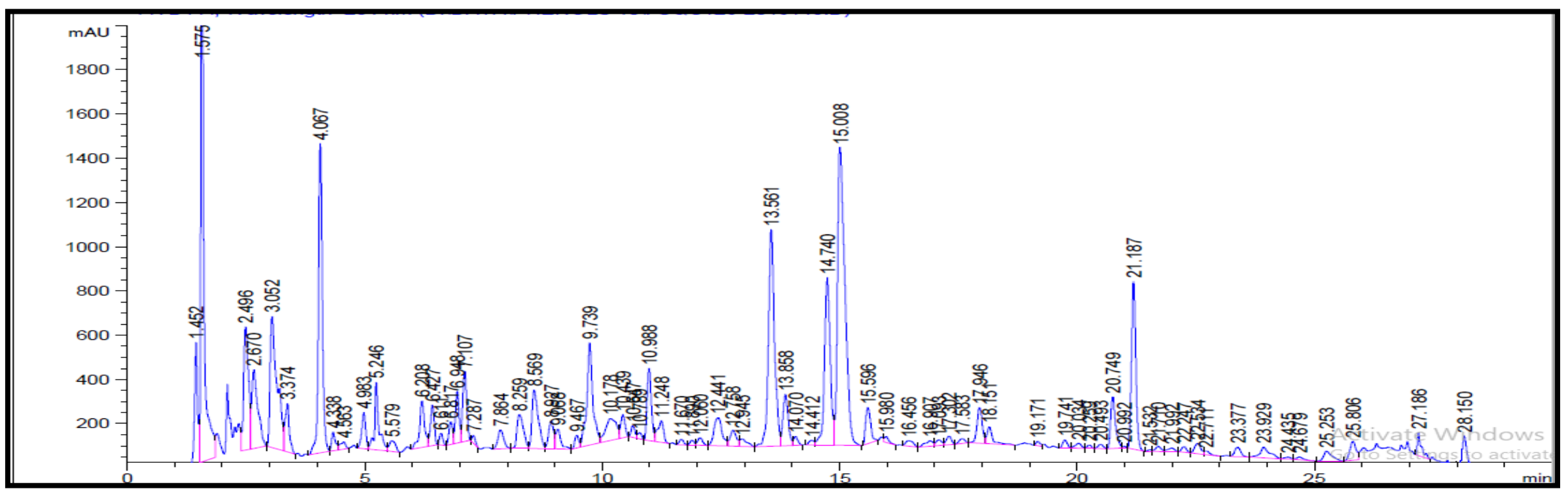

Fig. 1. HPLC chromatogram of phenolic extracts from roasted defatted flaxseed flour (RDFF).

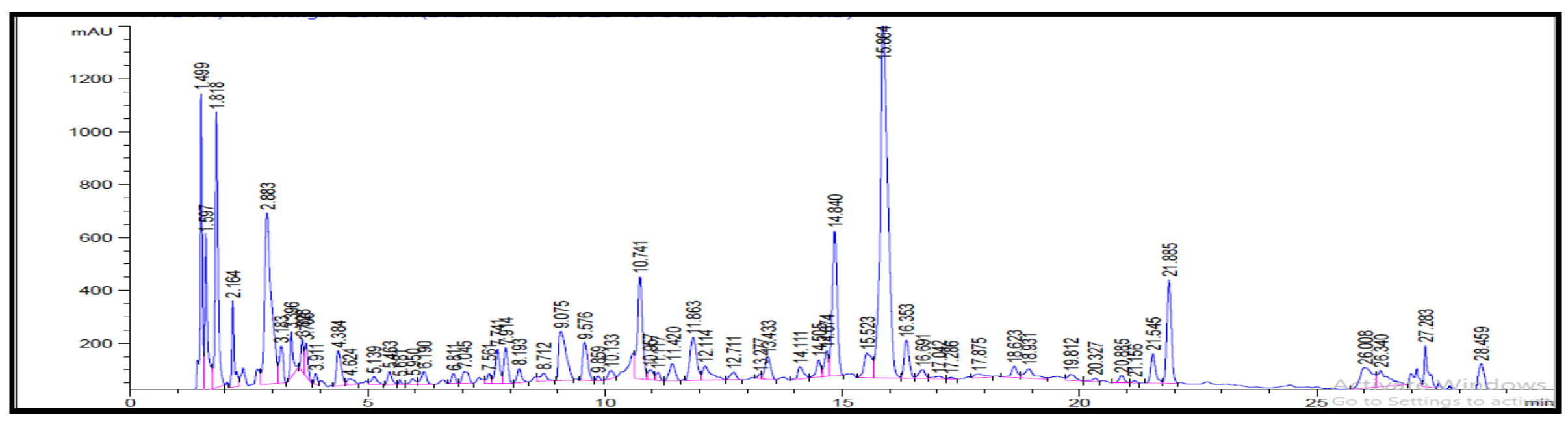

Fig. 2. HPLC chromatogram of phenolic extracts from defatted flaxseed flour (DFF). 


\subsection{Lignans fractions of flaxseed flours}

Data in Table (4) shows the lignans compounds of different flaxseed flours by HPLC. It was observed that, SDG is the predominant lignans precursor present in flaxseed. Also, it could be noticed that there was a large variability in the lignans content and SDG concentration of full fat flaxseed and defatted flaxseed samples. Defatted and roasted defatted flaxseed flours were higher in lignans values compared to that of full fat and roasted full fat flaxseed flours.

Table 4. Lignans fractions of flaxseed flours as $\mathrm{mg} / 100 \mathrm{~g}$ (on dwt).

\begin{tabular}{ccccc}
\hline Lignans compounds & FFF & RFFF & DFF & RDFF \\
\hline Pinoresinol & 1.52 & 1.59 & 2.46 & 3.79 \\
Syringaresinol & 2.67 & 3.02 & 5.71 & 6.19 \\
Lariciresinol & 13.97 & 16.59 & 25.63 & 31.91 \\
Mecoisolariciresinol diglucoside (SDG) & 130.97 & 138.02 & 148.07 & 160.72 \\
Matairesinol & 40.90 & 45.85 & 53.33 & 57.99 \\
Hydroxymatairesinol & 3.14 & 4.48 & 7.62 & 8.34 \\
Total lignans (mg/100g) & 193.17 & 209.55 & 242.82 & 268.94 \\
\hline
\end{tabular}

These data are close to Milder et al. (2005) who found that flaxseed lignans precursors were 871 $(\mu \mathrm{g} / 100 \mathrm{~g})$ pinoresinol and 165759 ( $\mu \mathrm{g} / 100 \mathrm{~g})$ secoisolariciresinol, Moreover, Toure and Xueming (2010) reported that lignans content in flaxseed is principally composed of secoisolariciresinol diglucoside (SDG).

3. Anticancer activity of ethanolic extracts of defatted and roasted defatted flaxseed

Results in Tables (5 and 6) and Fig. (3) showed that the in vitro cytotoxicity of freeze-dried ethanolic extracts of lignans obtained from defatted and roasted defatted flaxseed samples on colon carcinoma cell line (HCT) and breast carcinoma cell line (MCF-7). As shown in Table (5), Results revealed that the highest inhibition percents of defatted flaxseed ethanolic extract toward the colon carcinoma cell line (HCT) and breast carcinoma cell line (MCF-7) were 52 and $40.1 \%$ at concentration 50 and $100 \mu \mathrm{g} / \mathrm{ml}$, respectively.

The results also indicated that anticancer activity of flaxseed lignans increased as the extract concentration increased. Defatted flaxseed ethanolic extract had $\mathrm{IC}_{50}$ against colon carcinoma cell line (HCT) with value $48.2 \mu \mathrm{g} / \mathrm{ml}$. In contrast, no $\mathrm{IC}_{50}$ value was observed against breast carcinoma cell line (MCF-7) until concentrations under the study.

Regarding to the cytotoxic activity of roasted defatted flaxseed ethanolic extract on colon carcinoma cell line (HCT) and breast carcinoma cell line (MCF7) is presented in Table (6). The data related to HCT showed that the inhibition percent were 19.3, 41.8 and $71.6 \%$ at the concentrations $12.5,25$ and $50 \mu \mathrm{g} / \mathrm{ml}$, whereas the highest inhibition percent was observed at $100 \mu \mathrm{g} / \mathrm{ml}$ and the value was $80.8 \%$.

Concerning breast carcinoma cell line (MCF-7), it was observed that the highest inhibition percent was $70.1 \%$ at $50 \mu \mathrm{g} / \mathrm{ml}$ followed by $59.3 \%$ at $100 \mu \mathrm{g} / \mathrm{ml}$, while at the concentrations 12.5 and $25 \mu \mathrm{g} / \mathrm{ml}$ the inhibition percent was 20.2 and $46.8 \%$.

In addition, roasted defatted flaxseed ethanolic extract had $\mathrm{IC}_{50}$ against colon carcinoma cell line (HCT) with value $31.4 \mu \mathrm{g} / \mathrm{ml}$ and $29.0 \mu \mathrm{g} / \mathrm{ml}$ of $\mathrm{IC}_{50}$ value was observed against breast carcinoma cell line (MCF-7).

Ezzat et al. (2018) studied the in vitro cytotoxic potentiality of lignans fraction of six flaxseed cultivars (Sakha 1, Sakha 2, Sakha 3, Sakha 4, Giza 9 and Giza 10) against breast cancer cell lines (MCF-7 and T47D). $\mathrm{IC}_{50}$ of HCT and MCF-7cell lines were varied between 17.4 to 24.6 and 13.8 to $21.3 \mu \mathrm{g} / \mathrm{ml}$ among different flaxseed varieties. Giza 9 showed the most significant cytotoxic activity against breast cell lines MCF7 and T47D with $\mathrm{IC}_{50} 13.8$ and $15.8 \mu \mathrm{g} / \mathrm{ml}$, respectively. They also explained the high anticancer activity of Giza 9 could be attributed to its highest content of SDG $(81.64 \mathrm{mg} / \mathrm{g})$ as shown by the HPLC analysis. Their antioxidant activity is also one of the possible anti-carcinogenic mechanisms of the compounds.

From above mentioned data, it could be clear that lignans ethanolic extract of flaxseed had cytotoxic effect on (HCT) and (MCF-7) cell lines. Furthermore, roasted defatted flaxseed had strong anticancer activity toward two tested cell lines especially (MCF7) cell line. While, defatted flaxseed revealed anticancer activity against (HCT) cell line compared to $(\mathrm{MCF}-7)$ cell line. 


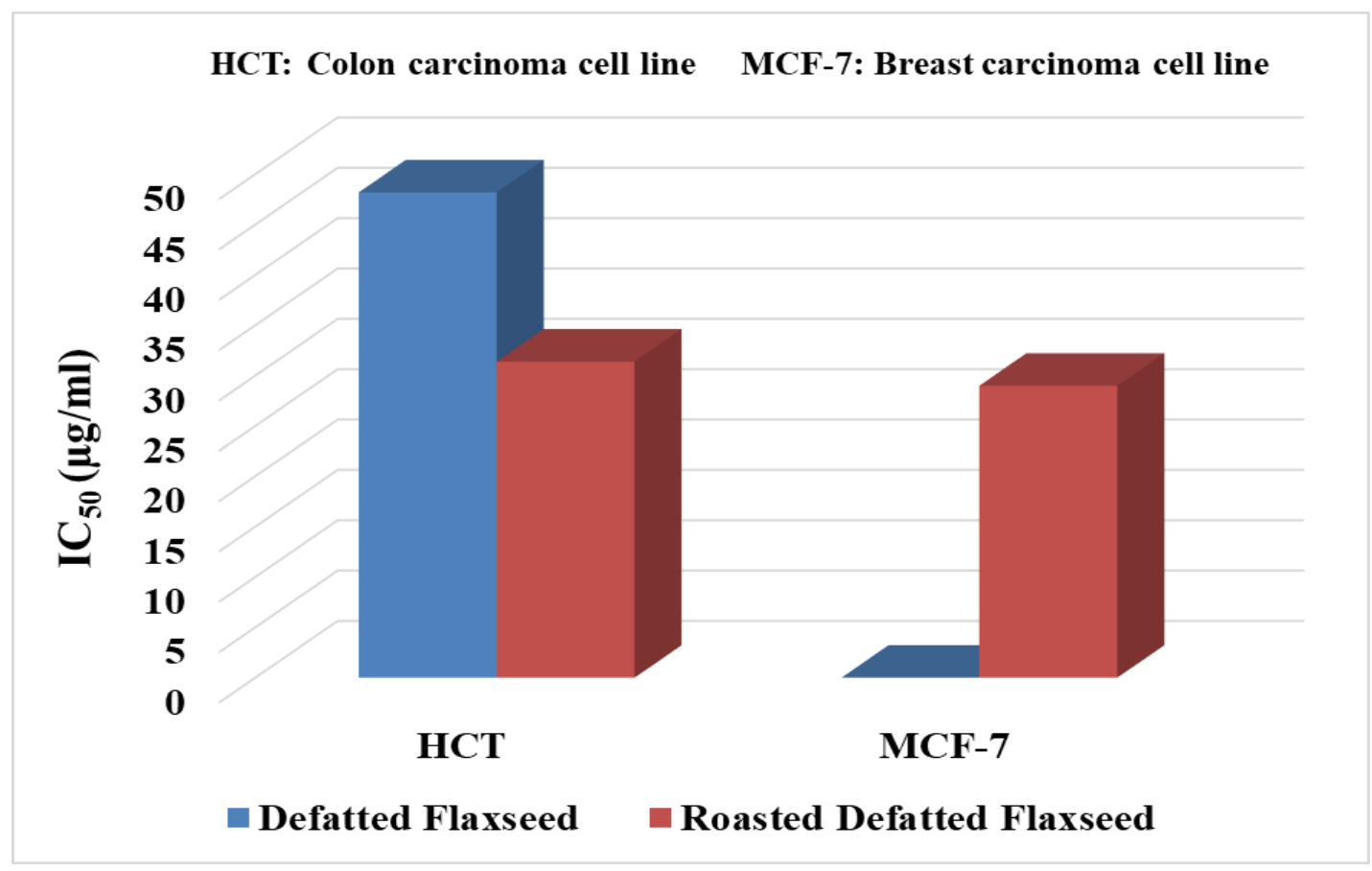

Fig. 3. $\mathrm{IC}_{50}$ of lignan ethanolic extracts of defatted and roasted defatted flaxseed on different cell lines.

Table 5. Inhibition percent $(\%)$ of ethanolic extract of defatted flaxseed lignans on different carcinoma cell lines.

\begin{tabular}{|c|c|c|c|c|c|c|c|c|c|}
\hline \multirow{3}{*}{$\begin{array}{l}\text { Cell } \\
\text { lines }\end{array}$} & \multicolumn{9}{|c|}{ Extract concentrations $(\mu \mathrm{g} / \mathrm{ml})$} \\
\hline & \multicolumn{2}{|c|}{12.5} & \multicolumn{2}{|c|}{25} & \multicolumn{2}{|c|}{50} & \multicolumn{2}{|c|}{100} & \multirow[b]{2}{*}{$\mathrm{IC}_{50}$} \\
\hline & $\begin{array}{l}\text { Surviving } \\
\text { cell } \times 10^{4}\end{array}$ & $\begin{array}{c}\text { Inhibition* } \\
(\%)\end{array}$ & $\begin{array}{l}\text { Surviving } \\
\text { cell } \times 10^{4}\end{array}$ & $\begin{array}{c}\text { Inhibition } \\
(\%)\end{array}$ & $\begin{array}{l}\text { Surviving } \\
\text { cell } \times 10^{4}\end{array}$ & $\begin{array}{c}\text { Inhibition } \\
(\%)\end{array}$ & $\begin{array}{l}\text { Surviving } \\
\text { cell } \times 10^{4}\end{array}$ & $\begin{array}{c}\text { Inhibition } \\
(\%)\end{array}$ & \\
\hline $\begin{array}{l}\text { Colon } \\
\text { cancer } \\
\text { (HCT) }\end{array}$ & 0.952 & 4.8 & 0.754 & 24.6 & 0.480 & 52.0 & 0.489 & 51.1 & 48.2 \\
\hline $\begin{array}{c}\text { Breast } \\
\text { cancer } \\
\text { (MCF- } \\
7)\end{array}$ & 0.872 & 12.8 & 0.785 & 21.5 & 0.645 & 35.5 & 0.599 & 40.1 & $\mathrm{ND}^{* *}$ \\
\hline
\end{tabular}

Table 6. Inhibition percent $(\%)$ of ethanolic extract of roasted defatted flaxseed lignans on different carcinoma cell lines.

\begin{tabular}{|c|c|c|c|c|c|c|c|c|c|}
\hline \multirow[b]{3}{*}{ Cell lines } & \multicolumn{9}{|c|}{ Extract concentrations $(\mu \mathrm{g} / \mathrm{ml})$} \\
\hline & \multicolumn{2}{|c|}{12.5} & \multicolumn{2}{|c|}{25} & \multicolumn{2}{|c|}{50} & \multicolumn{2}{|c|}{100} & \multirow[b]{2}{*}{$\mathrm{IC}_{50}$} \\
\hline & $\begin{array}{c}\text { Available } \\
\text { cell } \times \\
10^{4}\end{array}$ & $\begin{array}{c}\text { Inhibition* } \\
(\%)\end{array}$ & $\begin{array}{l}\text { Available } \\
\text { cell } \times 10^{4}\end{array}$ & $\begin{array}{c}\text { Inhibition } \\
(\%)\end{array}$ & $\begin{array}{l}\text { Available } \\
\text { cell } \times 10^{4}\end{array}$ & $\begin{array}{c}\text { Inhibition } \\
(\%)\end{array}$ & $\begin{array}{l}\text { Available } \\
\text { cell } \times 10^{4}\end{array}$ & $\begin{array}{c}\text { Inhibition } \\
(\%)\end{array}$ & \\
\hline $\begin{array}{l}\text { Colon } \\
\text { cancer } \\
(\mathrm{HCT})\end{array}$ & 0.807 & 19.3 & 0.582 & 41.8 & 0.284 & 71.6 & 0.192 & 80.8 & 31.4 \\
\hline $\begin{array}{c}\text { Breast } \\
\text { cancer } \\
(\mathrm{MCF}-7)\end{array}$ & 0.798 & 20.2 & 0.532 & 46.8 & 0.299 & 70.1 & 0.407 & 59.3 & 29.0 \\
\hline
\end{tabular}

*Inhibition $=[100-($ available cells $\times 100)]$ 


\section{Conclusions}

The results of this study concluded that flaxseed considered as a valuable source of biological active compounds particularly lignans and phenolic antioxidant, the highest lignans content was observed in defatted and roasted defatted flaxseed flours. Also, RDFF and DFF had the highest content of total phenolic and antioxidant activity. The high contents of phenolic compounds indicated that these compounds contribute to the antioxidant activity. The anticancer activity of flaxseed lignans increased as the extract concentration increased. Roasted defatted flaxseed had strong in vitro cytotoxicity toward breast carcinoma cell lines (MCF-7). While, defatted flaxseed revealed anticancer activity against colon carcinoma cell line (HCT). Thus, flaxseed could be a good choice of natural antioxidants and anticancer, which may have potential application in health and food industry.

\section{References}

AOAC (2012). Official Methods of Analysis of Association of Official Analytical Chemists International. 19 $9^{\text {th }}$ Ed. Association of Official Analytical Chemists. (Ed. Latimer, G. W.), Washington, DC, USA.

Bernacchia, R.; Preti, R. and Vinci, G. (2014). Chemical composition and health benefits of flaxseed. Austin J. Nutr. Food Sci., 2(8):10451053.

Brand-Williams, W.; Cuvelier, M. E. and Berset, C. (1995). Use of a free radical method to evaluate antioxidant activity. LWT-Food Technol., 28:2530.

Chetana, M. L. S.; Khyrunnisa, B. and Ramasarma, P. R. (2010). Nutritional characteristics of linseed/flaxseed (Linum Usitatissimum) and its application in muffin making. J. Texture Studies, 41:563-578.

Ezzat, S. M.; Shouman, S. A.; Elkhoely, A.; Attia, Y. M.; Elsesy, M. S.; El Senousy, A. S.; Choucry, M. A.; El Gayed, S. H.; El Sayed, A. A.; Sattar, E. A. and El Tanbouly, N. (2018). Anticancer potentiality of lignan rich fraction of six flaxseed cultivars. Scientific Reports, 8:544560.

Gaafar, A. A.; Salama, Z. A.; Askar, M. S.; ElHariri, D. M. and Bakry, B. A. (2013). In vitro antioxidant and antimicrobial activities of lignan flaxseed extract (Linum usitatissimum L.). Int. J. Pharm. Sci. Rev. Res., 23(2):291-297.

Hakkinen, S. H.; Karenlampi, S. O.; Heinonen, I. M.; Mykkanen, H. M. and Torronen, A. R. (1998). HPLC method for screening of flavonoids and phenolic acids in berries. J. Sci. Food Agric., 77:543-551.

Han, H.; Yılmaz, H. and Gülçin, I. (2018). Antioxidant activity of flaxseed (Linum usitatissimum L.) shell and analysis of its polyphenol contents by LC-MS/MS. Rec. Nat. Prod. 12(4): 397-402.

Hao, M. and Beta, T. (2012). Development of Chinese steamed bread enriched in bioactive compounds from barley hull and flaxseed hull extracts. Food Chem., 133:1320-1325.

Jhala, A. (2010). Flax (Linum usitatissimum L.): current uses and future applications. Australian J. Basic and Applied Sci., 4 (9): 4304-4312.

Jheimbach, L. L. C. and Port Royal, V. A. (2009). Determination of the GRAS status of the addition of whole and milled flaxseed to conventional foods and meat and poultry products.

Khan, A. and Saini, C. S. (2016). Effect of roasting on physicochemical and functional properties of flaxseed flour. Cogent Engineering, 3: 1-14.

Manukumar, H. M. and Thribhuvan, K. R. (2014). In-vitro evaluation of physicochemical, antioxidant and anti-inflammatory activity of pomegranate (Punica grantum .L) juice and seed hydro extracts. Int. J. Pharm. Bio. Sci., 5(1): 131141.

Manukumar, H. M.; Prathima,V. R.; Lokesh, S.; Goutham, G. and Suresha, S. (2014). Impact of partial defatting on nutritional, mineral, functional properties and effect of solvents to evaluate invitro antioxidant, antidiabetic potentiality from flaxseed (Linum usitatissimum) extracts. World J. Pharmacy Pharmaceutical Sci., 3(6): 1406-1427.

Marpalle, P.; Sonawane, S. K. and Arya, S. S. (2014). Effect of flaxseed flour addition on physicochemical and sensory properties of functional bread. LWT- Food Science and Technology, 58:614-619.

Milder, I. E.; Arts, I. C.; Van De Putte, B.; Venema, D. P. and Hollman, P. C. (2005). Lignan contents of Dutch plant foods: A database including lariciresinol, pinoresinol, secoisolariciresinol and matairesinol. Br. J. Nutr., 93(3): 393-402.

Mueller, K.; Eisner, P.; Yoshie-Stark, Y.; Nakada, R. and Kirchhoff, E. (2010). Functional properties and chemical composition of properties and chemical composition of Linum usitatissimum. J. Food Eng., 98(4): 453-460.

Omran, A. A.; Ibrahim, O. S. and Mohamed, Z. E. (2016). Quality characteristics of biscuit prepared from wheat and flaxseed flour. Advances in Food Sci., 38 (4):129-138.

Oomah, B. D. (2001). Flaxseed as a functional food source. J. Sci. Food Agric., 81: 889- 894.

Oomah, B. D. and Sitter, L. (2009). Characteristics of flaxseed hull oil. Food Chem., 114: 623-628.

Osman, M. A. (2004). Changes in sorghum enzyme inhibitors, phytic acid, tannins and in vitro protein digestibility occurring during Khamir (local bread) fermentation. Food Chem., 88:129-134.

Pittia, P.; Dalla, R. M. and Lerici, C. R. (2001). Textural changes of coffee beans as affected by 
roasting conditions. LWT-Food Sci. Technol., 34:168-175.

Price, M. L.; Socoyoc, S. V. and Butler, L. G. (1978). A critical evaluation of vanillin reaction as an assay for tannin in sorghum grain. J. Agric. Food Chem., 26(5):1214-1218.

Rubilar, M.; Gutierrez, C.; Verdugo, M.; Shene, C. and Sineiro, J. (2010). Flaxseed as a source of functional Ingredients. J. Soil Sci. Plant Nutr., 10: 373-377.

Simbalista, R. L.; Frota, K. D. M. G.; Soares, R. A. M. and Arêas, J. A. G. (2012). Effect of storage and processing of Brazilian flaxseed on lipid and lignan contents. Food Sci. Technol., 32: 374-380.

Skehan, P.; Storeng, R.; Scudiero, D.; Monks, A.; McMahon, J.; Vistica, D.; Warren, J. T.; Bokesch, H.; Kenney, S. and Boyd, M. R. (1990). New colorimetric cytotoxicity assay for anticancer-drug screening. J. National Cancer Institute, 82 (13): 1107-1112.

Steel, R. G. D. and Torrie, J. H. (1997). Principles and procedures of statistics. A biometrical approach. McGraw-Hill Book Co., New York, USA, 633p.

Toure, A. and Xueming, X. (2010). Flaxseed lignans: Source, biosynthesis, metabolism, antioxidant activity, bioactive components, and health benefits. Comprehensive Reviews in Food Sci. and Food safety, 9: 261-269.

Wang, H., Wang, J., Qiu, C., Ye, Y., Guo, X., Chen, G., Li, T., Wang, Y., Fu, X. and Liu, R. H. (2017). Comparison of phytochemical profiles and health benefits in fiber and oil flaxseeds (Linum usitatissimum L.), Food Chem., 1(214): 227-233.

Zhang, Z.; Li, D.; Wang, L.; Ozkan, N.; Chen, X. D.; Mao, Z. and Yang, H. (2007). Optimization of ethanol-water extraction of lignans from flaxseed. Separation and Purification Technology, 57:17-24.

Zhishen, J.; Mengcheng, T. and Jianming, W. (1999). The determination of flavonoid contents in mulberry and their scavenging effects on superoxides radicals. Food Chem., 64:555-559. 


\section{المواد الفعالة النشطة بيولوجيا في بذور الكتان كمضادات أكسدة طبيعية ومضادات للأورام السرطانية

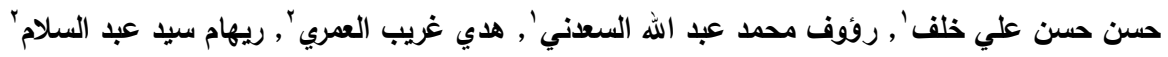

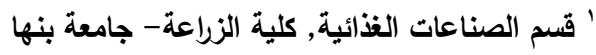

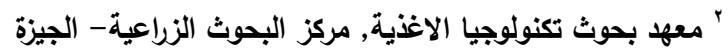

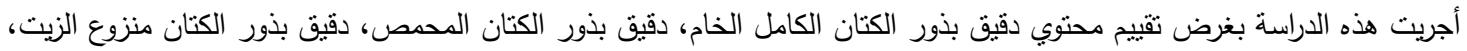

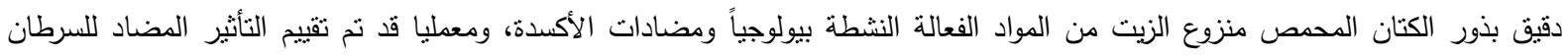

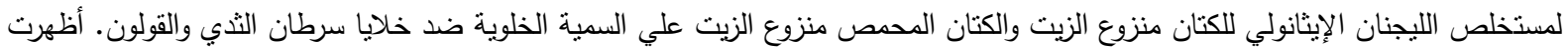

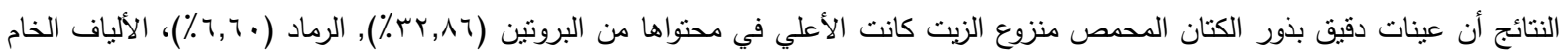

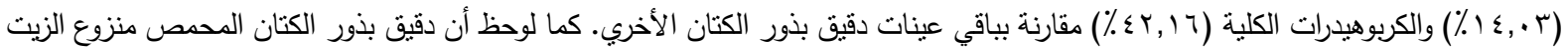

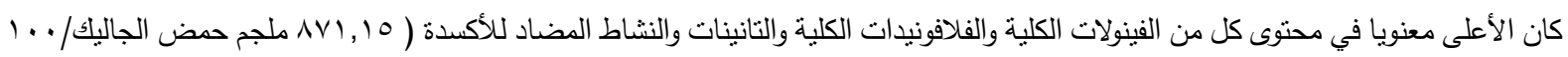

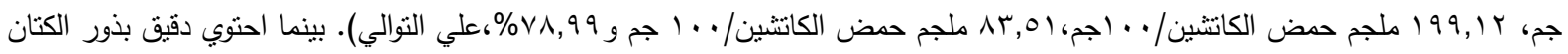

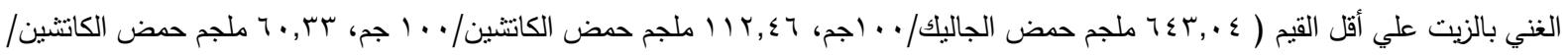

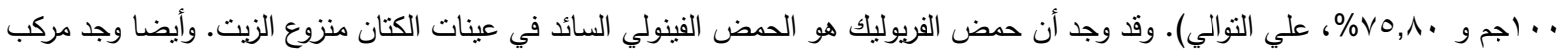
Secoisolariciresinol diglucoside (SDG) الزيت و دقيق بذور الكتان المحص منزوع الزيت أعلى في قيم الليجنان مقارنة بدقيق بذور الكتان الغني بالزيت والمحمص الغني بالزيت. وأثشارت

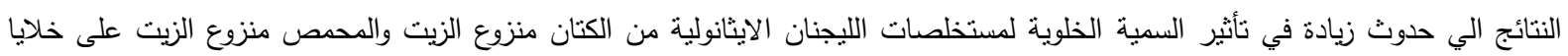

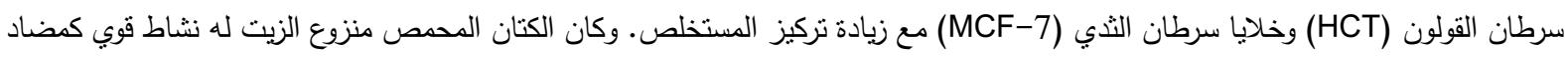
لنوعين الخلايا السرطانية الني تم اختبارها في هذه الدراسة (سرطان القولون والثني) حيث كانت قيمة الجرعة المسبية لموت نصف الخالايا (IC

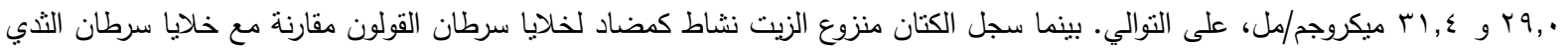

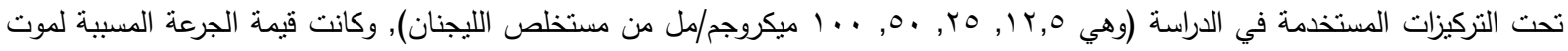

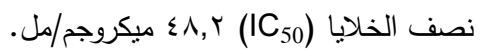
الكلمات الدالة: الكتان, دقيق بذور الكتان منزوع الزيت, دقيق بذور الكتان المحمص, المواد الفعالة النشطة بيولوجيا, النشاط المضاد للأكسدة, النشاط المضاد للأورام السرطانية. 